\title{
Insurance Services with Special Reference to Star Health and Allied Insurance Company Limited
}

\author{
Kirthi, S Praveen Kumar, Prasath
}

\begin{abstract}
Medical coverage is budgetary instrument with which individuals are shielded against catastrophic financial weight emerging from unforeseen disease or damage. Having a well working protection system ensures pooling of assets to cover dangers. The medical coverage segment in India is in a beginning stage and a mere $9 \%$ of the complete populace is secured under any plan of medical coverage since Health Insurance policies are administrations and henceforth elusive in nature. So there is no prompt shot of acknowledging the services whether fortunate or unfortunate. Indian Insurance Industry has encountered a swelling impact after globalization and the progression of the economy. After the financial advancement, the paradigm changed from focal arranging, direction and control to showcase driven improvement. The level of buying of medical coverage shifts from individual to individual. It relies on numerous variables. The elements can be classified into individual, social, financial, mental and friends related factors. On the off chance that the health insurance business wishes to pull its weight in forming this immense market, it needs to examine the major factors impacting the buy of medical coverage arrangements, With rivalry developing perpetually, insurers need to be in the nonstop procedure of item advancement concoct inventive approaches to contribute toward actualizing the administration's need of offering medical coverage to poor. The current health insurance projects required considerable changes to make them increasingly effective and socially helpful.
\end{abstract}

Keywords : Insurance, Liberalization, Garrett Point, Policy Holders, Health Insurance, TPA's, Claims.

\section{INTRODUCTION}

The Marketing of medical coverage strategies include exceptional practices when contrasted with showcasing of some other item. Medical coverage strategies are administrations and consequently elusive in nature. So there is no prompt shot of understanding the administrations whether positive or negative. It is the business power to battle

Revised Manuscript Received on July 22, 2019.

Kirthi Student,Department of MBA,Bharath institute of Higher Education \& Research,Tamilnadu,India, Email: kirthi@yahoo.com

Dr S Praveen Kumar, Director,Department of MBA,Bharath institute of Higher Education \& Research, Tamilnadu, India, Email: praveenkumar.mba@bharathuniv.ac.in

Prasath Department of Biomedical Engineering, ,Bharath institute of Higher Education \& Research, Tamilnadu, India, Email: prasathaliassurendhars@yahoo.com a lot to persuade the purchasers in all regards before emerging an agreement

Protection is characterized as a co-usable gadget to spread the misfortune brought about by a specific hazard, over various people who are presented to it and who consent to guarantee themselves against that chance. Hazard is vulnerability of a money related misfortune. The term hazard might be characterized as the likelihood of unfavorable outcomes spilling out of any event. Hazard emerges along these lines out of vulnerability. It can likewise speak to the likelihood of a result being not quite the same as the normal. The term hazard is utilized in protection business to likewise mean either a danger to be safeguarded against (For eg: Fire is hazard to which property is uncovered) or an individual or property ensured by protection. [1], [3],[5]

Hazard can be ordered into following classifications:

- Financial and Non-monetary dangers

- Static and Dynamic dangers

- Fundamental and Particular dangers.

- Pure and theoretical dangers. [2],[4],[6]

Among the accompanying groupings just unadulterated dangers are insurable. Protection is not worried about assurance of people against those misfortunes emerging out of speculative dangers. Estimating dangers are deliberately acknowledged due to its two dimensional nature, which incorporates the likelihood of addition. Each hazard includes the loss of one or other kind. The capacity of protection is to spread the misfortune over countless people who are consented to co-work each other at the season of misfortune. The misfortune is shared by them by installment of premium which is determined on the likelihood of misfortune. The protection is likewise characterized as a social gadget to aggregate assets to meet the dubious misfortunes emerging however a specific ascent to an individual guaranteed against the hazard. [7],[9] ,[11]

\section{RESEARCH DESIGN}

The researcher has used "descriptive research design" in this present study . [31],[33]Descriptive research is a study designed to depict the participants in an accurate way. The three main ways to collect this information are: Observational, defined as a method of viewing and recording the participants. Case study, defined as an in-depth study of an individual or group of individuals. [8],[ 10] ,[12] 


\section{A. Method of Data Collection}

Information accumulation is the orderly assembling of information for a specific reason from different sources including surveys, interviews, perception, existing records and electronic gadgets. [13], [15], [ 17]

The present investigation depends on essential information gathered from 107 respondents from the various pieces of Chennai city. A well-organized poll was intended to gather the data from the respondents the survey was intended to think about on representatives worry in IT division. Likert five point scales were utilized for acquiring reactions. The reactions have been gathered by methods for eye to eye interviews. [14],[ 16], [18]

There are different information gathering techniques that are utilized to explore different inquiries from shifted fields of study. It is commonly done through essential and optional information accumulation technique. A couple of issues are being explored utilizing contextual analysis technique which includes accumulation of information from various wellsprings of proof.

Confirmations are by and large being planned either by different sources, contextual analysis information bases and chain proof upkeep. Anyway the primary focal point of this investigation isn't for the extension of the given standards and arrangements yet to expand on the previously mentioned ideas and build up the outcomes dependent on various information accumulation technique for example meetings, reports and files and perception. [19],[21],[23]

\section{B. Primary data}

Primary data was collected through the structured questionnaire

\section{Secondary data}

The secondary data was collected from various Books, Journals, Articles, Newspapers, Magazines and Websites.

Sample size: In this survey the sample size decided was 107.

\section{SAMPLING METHOD}

Inspecting methodology: We received Intercept talk with technique for accumulation of essential information, as it is beyond the realm of imagination to expect to take arrangement from countless respondents. Motivation behind this exploration was advised to respondents and questions were disclosed to them on the off chance that there was any requirement for seeing a specific inquiry. There had been no close to home inclination or contortions were permitted while recording the reactions. [19],[21],[23]

\section{RESULTS \&DISCUSSION}

Normal Analysis and Percentage Analsis has been utilized in this investigation and pictorial represenatations have been worked out to introduce the information. [25],[27],[29]

Table No.1 The Telephone Calls Made By The Company Give Sufficient Information

\begin{tabular}{|l|l|l|}
\hline PARTICCLARS & FREQLENCY & PERCENTAGE \\
\hline Strondy disagee & 8 & 7.5 \\
\hline Disagee & 5 & 4.7 \\
\hline Neutral & 49 & 45.8 \\
\hline Aggee & 35 & 32.7 \\
\hline Strondy agee & 10 & 9.3 \\
\hline Total & 107 & 100 \\
\hline
\end{tabular}

Sources: Primary data

FIGURE NO 4.8 THE TELEPHONE CALLS MADE BY THE CONPANY GIVE SUFFICIENT INFORUATION

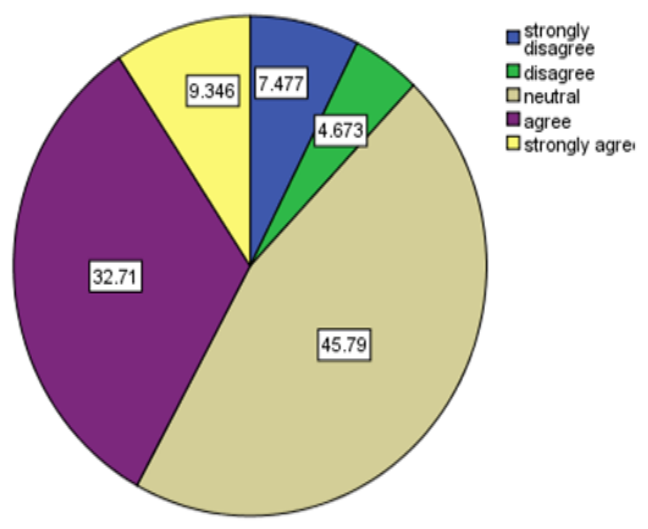

It very well may be seen from Table 4.8 that $7.5 \%$ of the respondents evaluated Strongly Disagree; $4.7 \%$ of the respondents appraised Disagree; $45.8 \%$ of the respondents appraised Neutral; $32.7 \%$ of the respondents evaluated Agree; and staying 9.3\% of the respondents appraised Strongly Agree.

TABLE NO.2 THE PAMPHLETS AND BROCHURES GIVE SUFFICIENT INFORMATION

\begin{tabular}{|l|l|l|}
\hline PARTICULARS & FREQUENCY & PERCENTAGE \\
\hline Strongly disagree & 4 & 3.7 \\
\hline Disagee & 6 & 5.6 \\
\hline Neutral & 38 & 35.5 \\
\hline Agree & 49 & 45.8 \\
\hline Strongly agree & 10 & 9.3 \\
\hline Total & 107 & 100 \\
\hline \\
Sources: Primary data \\
FIGURE N0 4.9 THE PAMPHLETS AND BROCHURES GIVE SUFFICIENT INFORMATION
\end{tabular}


FIGURE |THE PAMPHLETS AND BROCHURES GIVE SUFFICIENT INFORMATION

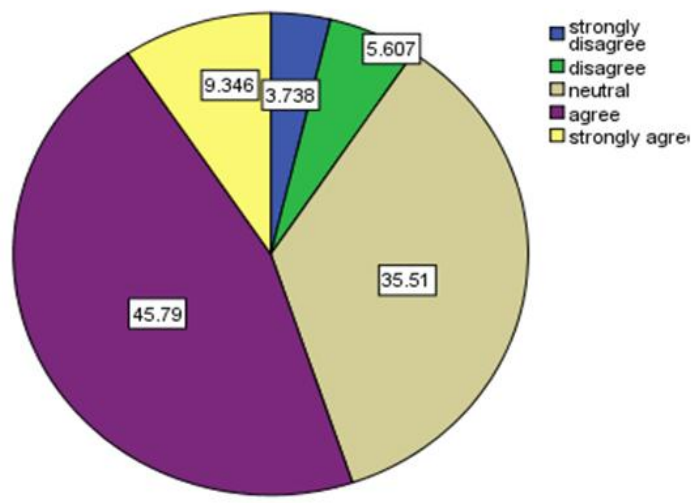

Table 3:The company offers diversified investment plan and policies

\begin{tabular}{|c|c|c|}
\hline PARTICULARS & FREQUENCY & PERCENTAGE \\
\hline Strondy disagee & 5 & 4.7 \\
\hline Disagee & 9 & 8.4 \\
\hline Neutral & 40 & 37.4 \\
\hline Aggee & 39 & 36.4 \\
\hline Strondy agree & 14 & 13.1 \\
\hline Total & 107 & 100 \\
\hline
\end{tabular}

Sources: Pimary data

FIGLRE NO 4.10 THE COMIPANY OFFERS DIIERSFFED INVESTMENT PLANS AND POLICTES

FIGURE NO 4.10 THE CONPANY OFFERS DIVERSFFIED INVESTIENT PLANS AND POLICIES

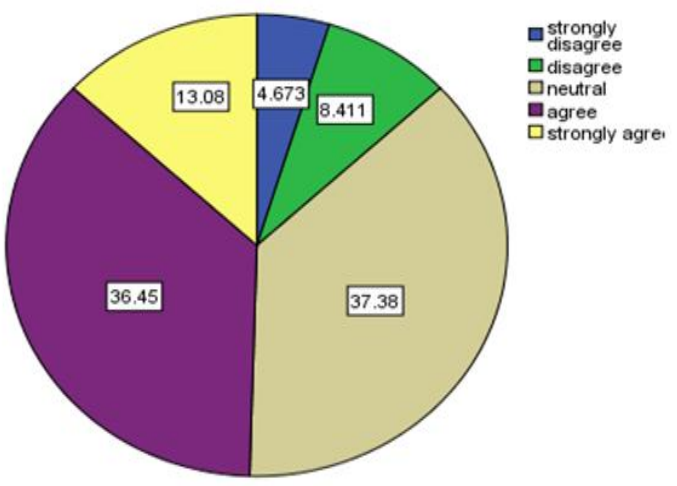

TABLE NO.4. The Marketing Executives Of The Company Have Adequate Knowledge To Influence Buying

TABLE N0.411 THE MARKETING EXECUTIVES OF THE CONPANY HAIE ADEQUATE KIOILLEDGE TOINLLENCE BUYING

\begin{tabular}{|l|l|l|}
\hline PARTICTZARS & FREQUENCY & PERCENTAGE \\
\hline Strongy disagee & 8 & 7.5 \\
\hline Disaggee & 5 & 4.7 \\
\hline Neutral & 49 & 45.8 \\
\hline Aggee & 35 & 32.7 \\
\hline Strongly agee & 10 & 9.3 \\
\hline Total & 107 & 100 \\
\hline
\end{tabular}

Sources: Primary data
TABLE NO.4. The Marketing Executives Of The Company Have Adequate Knowledge To Influence Buying

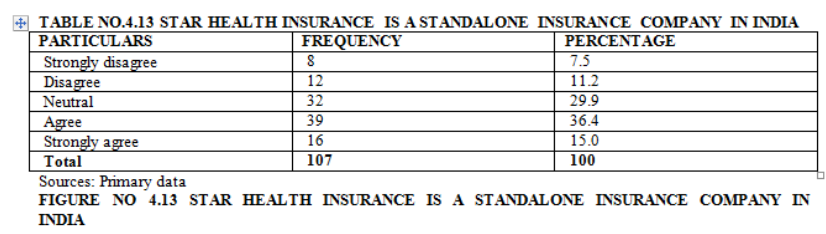
INDI

FIGURE NO 4.13 STAR HEALTH NNSURANCE IS A STANDALONE INSURANCE COMPANY IN INDIA

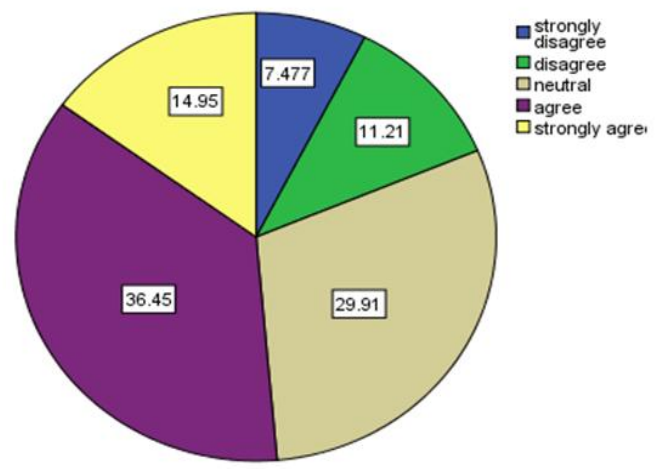

Table 5:The marketing executives advisorsare polite, knowledge ,and punctual in their approach

TABLE N0.4.12 THE MARKETING EXECUTIVES ADVISORS ARE POLITE, KNOWLEDGEABLE, AND PUNCTUAL IN THEIR APPROACH

\begin{tabular}{|l|l|l|}
\hline PARTICULARS & FREQUENCY & PERCENTAGE \\
\hline Strongly disagee & 8 & 7.5 \\
\hline Disagree & 9 & 8.4 \\
\hline Neutral & 41 & 38.3 \\
\hline Agree & 35 & 32.7 \\
\hline Strongly agee & 14 & 13.1 \\
\hline Total & 107 & 100 \\
\hline
\end{tabular}

Sources: Primary data

FIGURE NO 4.12 THE MARKETING EXECUTIVES ADVISORS ARE POLITE, KVOWLEDGEABLE, AND PUNCTUAL IN THEIR APPROACH

FIGURE NO 4.11 THE MARKETING EXECUTIVES OF THE COMPANY HAVE ADEQUATE KNOWLEDGE TO INLLENCE BUYING

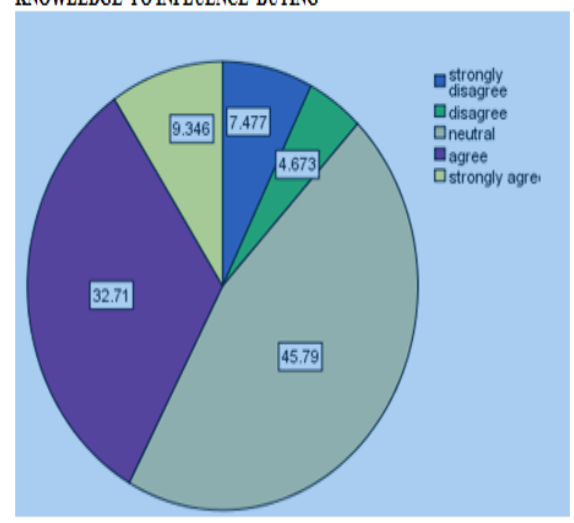

\section{CONCLUSION}

It is concluded that among the various factors influencing the policy holders perception on customer relationship management of Star health insurance "Quick Processing Factor" consisting of the variables such as the information enquired by the 
customer is quickly processed and given to the customers, the Toll free number can be contacted at any time during emergencies and Star health insurance sends seasonal greetings to the customers for family functions, occasions, etc. is found to be the most important factors influencing the policy holders perception on customer relationship management of Star health insurance. The next important factors influencing the policy holders perception on customer relationship management of Star health insurance is 'Quick grievance redressal Factor' which consists of the variables such as the Star health insurance offers huge network of famous hospitals in the city, Star health insurance has the grievance redressal all in the premises, Star health insurance settles the policy holders grievances very quickly and Proper reasons has been stated by the company in rejection of claims. It is concluded that policy holders have good perception towards the role of agents in selling products in the premium date has been reminded by the agent regularly

\section{REFERENCES}

1) BharthVajan R., Ramachandran S.,Psychographic dimensions of training,2016,International Journal of Pharmacy and Technology,V-8,I-4,P-23727-23729

2) Balakrishnan P., Bharthvajan R.,A study on human resource planning in hospitals in Chennai City,2014,International Journal of Applied Engineering Research,V-9,I-22,P-7503-7507

3) Priyadarsini P., Bharthvajan R.,Role of emotional intelligence training programme in reducing the stress of the nurses,2014,International Journal of Applied Engineering Research,V-9,I-22,P-7411-7421

4) Kerinab Beenu G., Bharthvajan R.,Empirical analysis on the cosmetic buying behavior of young women in South India,2014,International Journal of Applied Engineering Research,V-9,I-22,P-7361-7366

5) Balakrishnan P., Bharthvajan R.,Whistling in the wind,2014,International Journal of Applied Engineering Research,V-9,I-22,P-7586-7593

6) Krishnan B., Peter M.,Health hazards of Indian Bpo employee-an alarming issue,2014,International Journal of Applied Engineering Research,V-9,I-22,P-7336-7341

7) Kerinab Beenu G.H., Peter M.,Role of insurance in economic development,2014,International Journal of Applied Engineering Research,V-9,I-22,P-7532-7539

8) Balakrishnan P., Peter M., Priyadarsini P.,Efficiency of safety measures for wellbeing of employees in manufacturing industry,2014,International Journal of Applied Engineering Research,V-9,I-22,P-7376-7382

9) Anbarasi M., Praveen Kumar S.,Online sales promotions of herbal products and its effectiveness towards tanisha.com,2019,Indian Journal of Public Health Research and Development,V-10,I-1,P-195-200

10) Anbarasi M., Praveen Kumar S., Various online marketing and promotions strategies to improve the validation towards the organic products in the pharmaceutical sectors,2019,Indian Journal of Public Health Research and Development,V-10,I-1,P-263-269

11) Loganathan R., Praveen Kumar S.,Grievance handling a key factor for solving issues of employees in an organization,2014,International Journal of Applied Engineering Research,V-9,I-22,P-7483-7491

12) Loganathan R., Praveen Kumar S.,Study on preference of private label brands in super and Hypermarkets,2014,International Journal of Applied Engineering Research,V-9,I-22,P-7327-7335

13) Smitha M., Praveen Kumar S.,Understanding stress and its managementamong the nurses in Chennai city,2014,International Journal of Applied Engineering Research,V-9,I-22,P-7560-7565

14) Kerinab Beenu G.H., Praveen Kumar S.,A study on the investment behavior of Chennai investors in mutual fund schemes,2014,International Journal of Applied Engineering Research,V-9,I-22,P-7520-7525

15) Loganathan R., Praveen Kumar S.,Retention strategies key for organizational productivity,2014,International Journal of Applied Engineering Research,V-9,I-22,P-7443-7447

16) Pavithra J., Ganesan M., Brindha G.,State wise analysis of microfinance sector in India,2016,International Journal of Pharmacy and Technology,V-8,I-4,P-23417-23432

17) Pavithra J., Ganesan M.,A comparative study on microfinance in India and abroad,2016,International Journal of Applied Business and Economic Research,V-14,I-8,P-5471-5476

18) Pavithra J., Ganesan M.,A study on awareness and impact of micro-financial schemes,2016,International Journal of Applied Business and Economic Research,V-14,I-8,P-5449-5460
19) Senthilmurugan P., Pavithra J.,Consumer preference towards organised retailing with reference to Big Bazaar,2014,International Journal of Applied Engineering Research,V-9,I-22,P-7469-7475

20) Senthilmurugan P., Pavithra J.,Implication of social media marketing in growing healthcare industry,2014,International Journal of Applied Engineering Research,V-9,I-22,P-7448-7456

21) Loganathan R., Pavithra J.,Consumer perception towards private label brand over other brands in super markets and hypermarkets,2014,International Journal of Applied Engineering Research,V-9,I-22,P-7355-7360

22) Kerinab Beenu G., Pavithra J.,Tradeâ€"off between liquidity and profitability in logistics industry,2014,International Journal of Applied Engineering Research,V-9,I-22,P-7398-7401

23) Kerinab Beenu G., Pavithra J.,A study on the prospective consumerâ€ TM $_{S}$ perception towards utility cars in Chennai city,2014,International Journal of Applied Engineering Research,V-9,I-22,P-7526-7531

24) Pavithra J., Dilli Babu P., Ambuli T.V.,A study on budgetary control at Maruti Service Masters, Chennai,2014,International Journal of Applied Business and Economic Research,V-12,I-2,P-151-161

25) Pavithra J., Dilli Babu P., Ambuli T.V.,A study on customer satisfaction of retro Garments Pvt Ltd, Chennai,2014,International Journal of Applied Business and Economic Research,V-12,I-2,P-381-391

26) Kerinab Beenu G.H., Pavithra J., Senthilmurugan P.,A study on the influence of promotional activities for TATA ARIA among consumers in Chennai,2014,International Journal of Applied Engineering Research,V-9,I-22,P-7572-7578

27) Vijayaragavan S.P.,An investigative expert that's general FBG sensors,International Journal of Mechanical Engineering and Technology,V-8,I-8,PP-1500-1505,Y-2017

28) Vijayaragavan S.P.,Equalization routing protocol for Wi-Fi sensor strategy,International Journal of Mechanical Engineering and Technology,V-8,I-8,PP-1662-1666,Y-2017

29) Karthik B., Kiran Kumar T.V.U., Vijayaragavan P., Bharath Kumaran E.,Design of a digital PLL using 0.35 $\hat{\mathrm{I}}^{1} / 4 \mathrm{~m}$ CMOS technology, Middle East Journal of Scientific Research,V-18,I-12,PP-1803-1806,Y-2013

30) Kanniga E., Selvaramarathnam K., Sundararajan M.,Kandigital bike operating system,Middle - East Journal of Scientific Research,V

31) Jasmin M., Vigneshwaran T., Beulah Hemalatha S.,Design of power aware on chip embedded memory based FSM encoding in FPGA,International Journal of Applied Engineering Research,V-10,I-2,PP-4487-4496,Y-2015

32) Jasmin M.,Optimization techniques for low power VLSI circuits,Middle East Journal of Scientific Research,V-20,I-9,PP-1082-1087,Y-2014

33) Jasmin M., Vigneswaran T.,Fuzzy controller for error control of on - Chip communication,2017 International Conference on Algorithms, Methodology, Models and Applications in Emerging Technologies, ICAMMAET 2017,V-2017-January,I-,PP-1-5,Y-2017

\section{AUTHORS PROFILE}

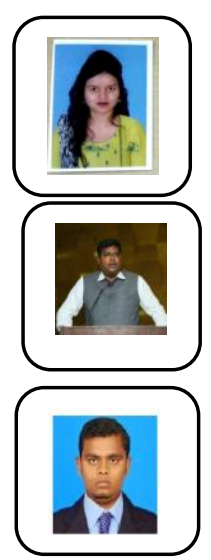

Kirthi Student,Department of MBA,Bharath institute of Higher Education \& Research,Tamilnadu,India

Dr S Praveen Kumar, Director, Department of MBA,Bharath institute of Higher Education \& Research,Tamilnadu,India,

Prasath Department of Biomedical Engineering, ,Bharath institute of Higher Education \& Research,Tamilnadu,India 